\title{
Emended description of the genus Actinokineospora Hasegawa 1988 and transfer of Amycolatopsis fastidiosa Henssen et al. 1987 as Actinokineospora fastidiosa comb. nov.
}

\author{
Correspondence \\ D. P. Labeda \\ David.Labeda@ars.usda.gov
}

D. P. Labeda, ${ }^{1}$ N. P. Price, ${ }^{2}$ G. Y. A. Tan, ${ }^{3}$ M. Goodfellow ${ }^{4}$ and H.-P. Klenk ${ }^{5}$

\author{
${ }^{1}$ Microbial Genomics and Bioprocessing Research Unit, National Center for Agricultural Utilization \\ Research, USDA - Agricultural Research Service, Peoria, IL 61604, USA \\ ${ }^{2}$ Bioproducts and Biocatalysis Research Unit, National Center for Agricultural Utilization Research, \\ USDA - Agricultural Research Service, Peoria, IL 61604, USA \\ ${ }^{3}$ Institute of Biological Sciences, Faculty of Science, University of Malaya, 50603 Kuala Lumpur, \\ Malaysia \\ ${ }^{4}$ School of Biology, University of Newcastle, Newcastle upon Tyne NE1 7RU, UK \\ ${ }^{5} \mathrm{DSMZ}$ - Deutsche Sammlung von Mikroorganismen und Zellkulturen GmbH, Braunschweig, \\ Germany
}

\begin{abstract}
The species Amycolatopsis fastidiosa (ex Celmer et al. 1977) Henssen et al. 1987 was proposed, based on morphological and chemotaxonomic observations, for a strain originally described as 'Pseudonocardia fastidiosa' Celmer et al. 1977 in a US patent. In the course of a phylogenetic study of the taxa with validly published names within the suborder Pseudonocardineae based on $16 \mathrm{~S}$ rRNA gene sequences, it became apparent that this species was misplaced in the genus Amycolatopsis. After careful evaluation of the phylogeny, morphology, chemotaxonomy and physiology of the type strain, it was concluded that this strain represents a species of the genus Actinokineospora that is unable to produce motile spores. The description of the genus Actinokineospora is therefore emended to accommodate species that do not produce motile spores, and it is proposed that Amycolatopsis fastidiosa be transferred to the genus Actinokineospora as Actinokineospora fastidiosa comb. nov. The type strain is NRRL B-16697 ${ }^{\top}$ $=$ ATCC $31181^{\top}=$ DSM $43855^{\top}=$ JCM $3276^{\top}=$ NBRC $14105^{\top}=$ VKM Ac- $1419^{\top}$.
\end{abstract}

The name 'Pseudonocardia fastidiosa' was proposed by Celmer et al. (1977) for an actinomycete strain that displayed acropetal development of spore chains and which produced a macrobicyclic peptide antibiotic, although the name was never validly published. A subsequent study by Henssen et al. (1987) reported that the strain deviated from the typical morphology exhibited by the genus Pseudonocardia in that acropetal budding was not observed. Moreover, they noted that phosphatidylethanolamine was the predominant polar lipid (type PII sensu Lechevalier et al., 1977) rather than phosphatidylcholine (type PIII sensu Lechevalier et al., 1977), which is characteristic of Pseudonocardia. They proposed that this species be

The GenBank/EMBL/DDBJ accession number for the $16 \mathrm{~S}$ rRNA gene sequence of strain NRRL B-16697 ${ }^{\top}$ is GQ200601.

Whole-cell carbohydrate profiles of Actinokineospora riparia NRRL B$16432^{\top}$ and Amycolatopsis fastidiosa NRRL B-16697 ${ }^{\top}$ and details of the grouped sequences used in the construction of Fig. 1 are available as supplementary material with the online version of this paper. transferred to the genus Amycolatopsis as Amycolatopsis fastidiosa because these morphological and chemotaxonomic characteristics were typical of members of this genus. During the course of a recent phylogenetic analysis of all taxa within the suborder Pseudonocardineae on the basis of 16S rRNA gene sequences, it became obvious that this species is misplaced within the genus Amycolatopsis, and a study was undertaken to clarify its taxonomic position. In addition, it was noted that Amycolatopsis fastidiosa did not yield an amplification product using Amycolatopsis-specific oligonucleotide primers (Tan et al., 2006) and that Everest \& Meyers (2009) had determined that the gyrB sequence of Amycolatopsis fastidiosa was quite different (only 79.5-83.3\% similarity) from those of the other species of the genus.

Several 16S rRNA gene sequences for the type strain of Amycolatopsis fastidiosa are available in the public databases and, to confirm their accuracy, DNA was isolated from NRRL B-16697 ${ }^{\mathrm{T}}$, the type strain held in the ARS Culture Collection, using an UltraClean microbial DNA 
isolation kit (MoBio Laboratories). The 16S rRNA gene sequence was determined by standard procedures (Labeda \& Kroppenstedt, 2000). The sequence of NRRL B- $16697^{\mathrm{T}}$ was found to be identical to the other deposited sequences for this type strain (GenBank accession no. AJ400710 from IMSNU 20054 ${ }^{\mathrm{T}}$; AY389140 from AS $4.1172^{\mathrm{T}}$ ).

Phylogenetic analyses were performed on the aligned sequences of the type strains of all taxa currently described within the suborder Pseudonocardineae using ARB (Ludwig et al., 2004) and it was observed that Amycolatopsis fastidiosa was positioned consistently as the most distant member of the Actinokineospora genus clade (Fig. 1), which is quite far from that of the genus Amycolatopsis. The 16S rRNA gene sequence similarity of NRRL B- $16697^{\mathrm{T}}$ to the species within the genus Actinokineospora ranged from a high of $97.4 \%$ for Actinokineospora terrae NBRC $15668^{\mathrm{T}}$ (GenBank accession no. AB058394) to $95.7 \%$ for Actinokineospora enzanensis NBRC $16517^{\mathrm{T}}$ (AB058395), clearly suggestive of membership of this genus.
A key characteristic of all Actinokineospora species has been the production of motile spores. Morphological studies were performed on the media suggested by Shirling \& Gottlieb (1966) as well as a modified version of the humic acid medium introduced by Hayakawa \& Nonomura (1987) in which $0.1 \%$ yeast extract was substituted for the vitamin stock solution. The procedure of Tamura et al. (1995) was used to observe the strain for the presence of motile spores. Colonial growth from glycerol-asparagine agar or humic acid-yeast extract agar plates was suspended in $0.01 \mathrm{M}$ sodium phosphate buffer ( $\mathrm{pH} 7.0$ ) containing $10 \%$ soil extract (Lochhead \& Burton, 1957) and incubated for $30 \mathrm{~min}$ at $28{ }^{\circ} \mathrm{C}$ and aliquots were then observed by phasecontrast microscopy for the presence of motile spores. Amycolatopsis fastidiosa NRRL B-16697 ${ }^{\mathrm{T}}$ did not form motile spores on any of the media evaluated. Agar blocks containing colonial growth of NRRL B- $16697^{\mathrm{T}}$ were fixed with osmium tetroxide vapour, dehydrated though a graded acetone series, critical-point dried from liquid $\mathrm{CO}_{2}$ and sputter-coated with gold prior to observation using a JEOL

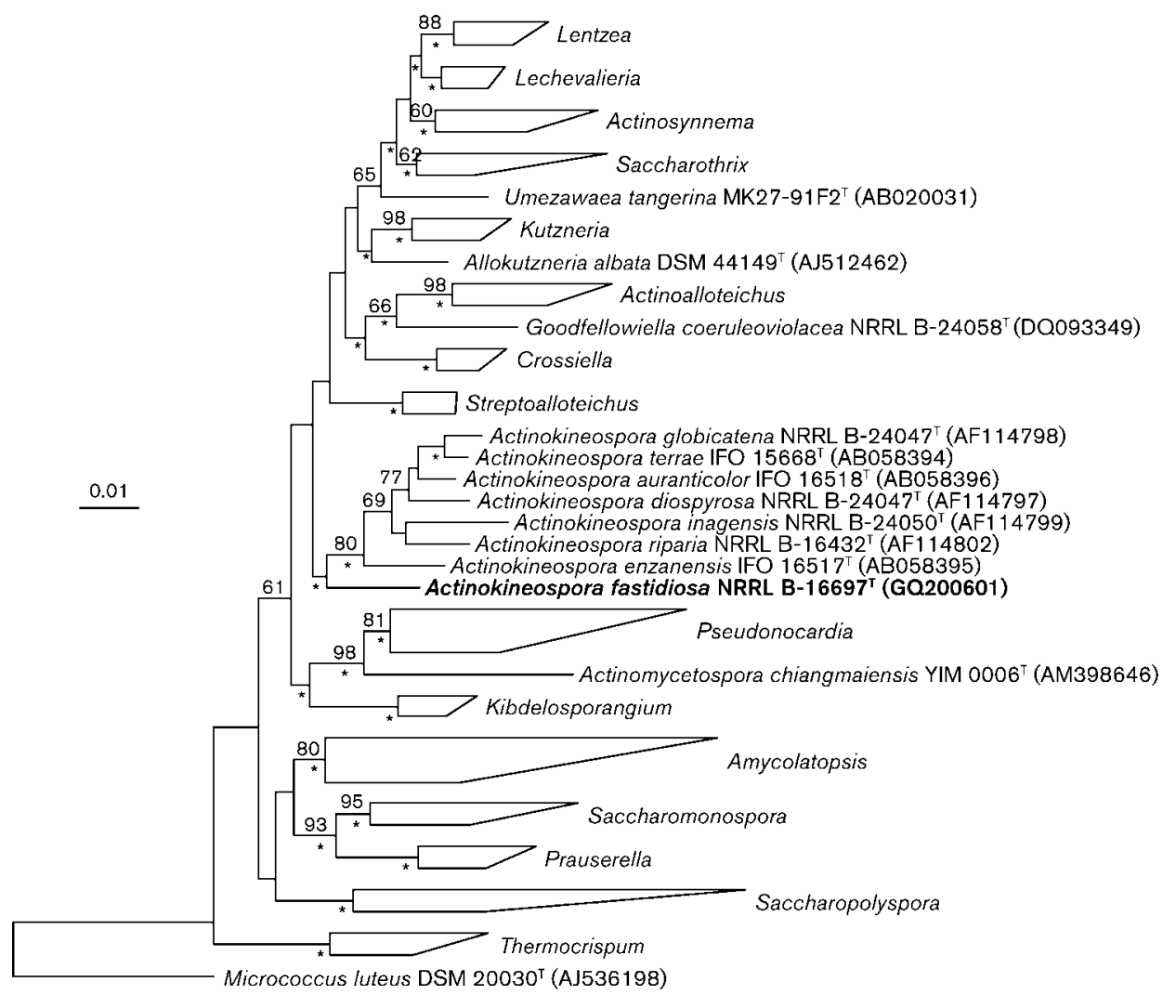

Fig. 1. Phylogenetic tree for taxa of the suborder Pseudonocardineae calculated within ARB (Ludwig et al., 2004) from almostcomplete 16S rRNA gene sequences using Kimura's two-parameter evolutionary distance method (Kimura, 1980) and the neighbour-joining method of Saitou \& Nei (1987) illustrating the taxonomic position of Amycolatopsis fastidiosa NRRL B$16697^{\top}$ relative to the other species of Actinokineospora and the other taxa within the suborder. Percentages at nodes represent levels of bootstrap support from 1000 resampled datasets; values less than $60 \%$ are not shown. Asterisks indicate that the corresponding branches were also recovered in maximum-parsimony (Felsenstein, 1993) and maximum-likelihood (Stamatakis et al., 2002) trees. Bar, 0.01 nucleotide substitutions per site. Details of the grouped sequences used in construction of the tree are given in Supplementary Table S1, available in IJSEM Online. 


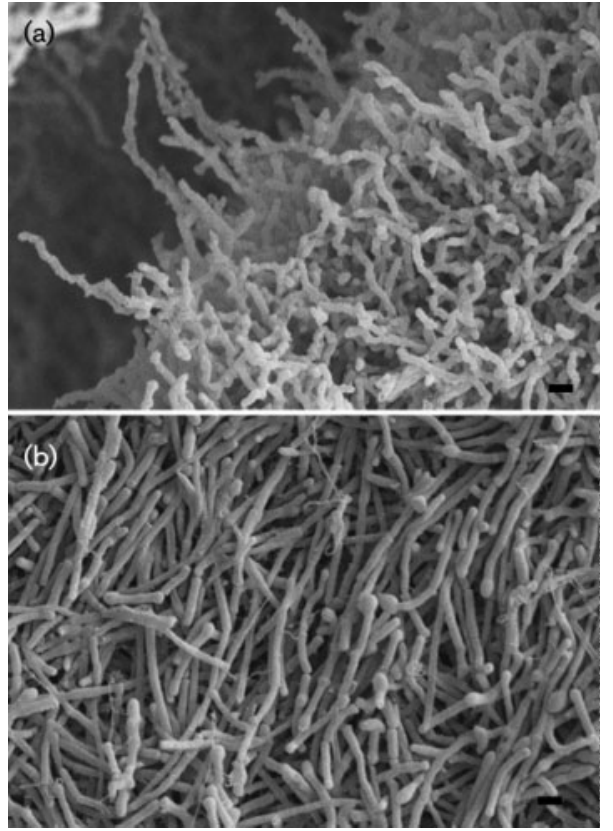

Fig. 2. Scanning electron micrograph of growth of Amycolatopsis fastidiosa NRRL B-16697 ${ }^{\top}$ incubated for 6 weeks on glycerolasparagine agar. Note the zigzag morphology of the aerial mycelium in (a) and the rod-shaped elements of varying length in (b) that may be spores. Bars, $1 \mu \mathrm{m}$. model JSM 6400V scanning electron microscope. The observations of Henssen et al. (1987) regarding the zigzag morphology of the aerial mycelium (Fig. 2a) and the production of smooth-surfaced, rod-shaped spores of varying length (Fig. 2b) were confirmed.

A comparison of the chemotaxonomic characteristics of Amycolatopsis fastidiosa, determined by the methods of Grund \& Kroppenstedt (1989), with those of phylogenetically nearest neighbouring genera (Table 1) provided strong evidence to support the placement of this taxon within the genus Actinokineospora, since it exhibits compositional traits virtually identical to those of species of this genus, including phosphatidylethanolamine and hydroxy fatty acid-containing phosphatidylethanolamine as the major polar lipids and MK-9 $\left(\mathrm{H}_{4}\right)$ as the predominant menaquinone. It was felt that the whole-cell sugar profile might be crucial; hence a quantitative determination of sugar composition was performed by hydrolysing $50 \mathrm{mg}$ freeze-dried biomass in $1.5 \mathrm{ml} 0.5 \mathrm{M} \mathrm{HCl}$ by autoclaving for $20 \mathrm{~min}$. The hydrolysate was neutralized after cooling by addition of $300 \mu \mathrm{l} 17 \mathrm{M} \mathrm{NH}_{4} \mathrm{OH}$ and then peracetylated aldononitrile derivatives of the sugars present were prepared and analysed by GC/MS by the method of Price (2004). The whole-cell sugar content of Amycolatopsis fastidiosa NRRL B-16697 ${ }^{\mathrm{T}}$ was compared directly with that of Actinokineospora riparia NRRL B-16432 ${ }^{\mathrm{T}}$, the type strain of the type species of Actinokineospora, and was found to be identical (Supplementary Fig. S1) in containing galactose with smaller quantities of arabinose, mannose and rhamnose, further supporting the placement of this species in the genus Actinokineospora.

Table 1. Comparison of the chemotaxonomic profile of Amycolatopsis fastidiosa NRRL B-16697 ${ }^{\top}$ with the phylogenetically nearest taxa

Taxa: 1, Amycolatopsis fastidiosa NRRL B-16697 ${ }^{\mathrm{T}}$; 2, Actinokineospora; 3, Actinoalloteichus; 4, Actinosynnema; 5, Allokutzneria; 6, Crossiella; 7, Goodfellowiella; 8, Kibdelosporangium; 9, Kutzneria; 10, Streptoalloteichus.

\begin{tabular}{|c|c|c|c|c|c|c|c|c|c|c|}
\hline Character & 1 & 2 & 3 & 4 & 5 & 6 & 7 & 8 & 9 & 10 \\
\hline Motile spores & - & + & - & + & - & - & - & - & - & + \\
\hline $\begin{array}{l}\text { Whole-cell } \\
\text { sugars }^{\star}\end{array}$ & $\begin{array}{l}\text { Gal, Ara, } \\
\text { Rha, Man }\end{array}$ & $\begin{array}{l}\text { Gal, Ara, } \\
\text { Rha, Man }\end{array}$ & $\begin{array}{l}\text { Glc, Gal, } \\
\text { Man, Rib }\end{array}$ & Gal, Man & $\begin{array}{l}\text { Ara, Gal, } \\
\text { Man }\end{array}$ & $\begin{array}{l}\text { Gal, Man, } \\
\text { Rha, Rib }\end{array}$ & Gal, Rib & $\begin{array}{l}\text { Ara, Gal, } \\
\text { Glc, Rha }\end{array}$ & Gal, Rha & $\begin{array}{l}\text { Gal, Man, } \\
\text { Rha, Rib }\end{array}$ \\
\hline Phospholipids $\dagger$ & $\begin{array}{l}\text { PE, OH-PE, } \\
\text { PI, DPG }\end{array}$ & $\mathrm{PE}, \mathrm{OH}-\mathrm{PE}$ & $\begin{array}{l}\text { PIM, PI, } \\
\text { PG, DPG, } \\
\text { PME }\end{array}$ & $\begin{array}{c}\text { PE, OH-PE, } \\
\text { PG }\end{array}$ & $\begin{array}{c}\text { PE, PME, } \\
\text { OH-PE, PI, } \\
\text { lyso-PME, } \\
\text { DPG, PG, } \\
\text { lyso-PE }\end{array}$ & $\begin{array}{l}\text { PE, DPG, } \\
\text { PI, PIM, } \\
\text { PME }\end{array}$ & $\begin{array}{c}\text { PE, DPG, } \\
\text { OH-PE, } \\
\text { PME }\end{array}$ & $\begin{array}{l}\text { PE, PME, } \\
\text { PG, PI }\end{array}$ & $\begin{array}{c}\text { PE, DPG, } \\
\text { PI, PG, } \\
\text { PME }\end{array}$ & $\begin{array}{c}\text { PE, DPG, } \\
\text { PI, PIM, } \\
\text { DPG, } \\
\text { PME }\end{array}$ \\
\hline $\begin{array}{l}\text { Predominant } \\
\text { menaquinone(s) }\end{array}$ & $\begin{array}{l}9\left(\mathrm{H}_{4}\right), \\
9\left(\mathrm{H}_{2}\right), \\
8\left(\mathrm{H}_{4}\right)\end{array}$ & $\begin{array}{c}9\left(\mathrm{H}_{4}\right), \\
7\left(\mathrm{H}_{4}\right), \\
8\left(\mathrm{H}_{4}\right)\end{array}$ & $9\left(\mathrm{H}_{4}\right)$ & $\begin{array}{r}9\left(\mathrm{H}_{4}\right) \\
9\left(\mathrm{H}_{6}\right)\end{array}$ & $9\left(\mathrm{H}_{4}\right)$ & $9\left(\mathrm{H}_{4}\right)$ & $\begin{array}{l}9\left(\mathrm{H}_{4}\right) \\
10\left(\mathrm{H}_{4}\right)\end{array}$ & $9\left(\mathrm{H}_{4}\right)$ & $9\left(\mathrm{H}_{4}\right)$ & $\begin{array}{l}9\left(\mathrm{H}_{6}\right) \\
10\left(\mathrm{H}_{6}\right)\end{array}$ \\
\hline $\begin{array}{l}\text { DNA G }+\mathrm{C} \\
\text { content }(\mathrm{mol} \%)\end{array}$ & 73 & $69.1-72.0$ & $72-72.5$ & 71 & 71.6 & 71.4 & 69.2 & 66 & $70.3-70.7$ & 71.6 \\
\hline
\end{tabular}

${ }^{\star}$ Ara, Arabinose; Gal, galactose; Glc, glucose; Man, mannose; Rha, rhamnose; Rib, ribose.

$\dagger$ DPG, Diphosphatidylglycerol; OH-PE, phosphatidylethanolamine with hydroxy fatty acids; lyso-PE, phosphatidylethanolamine where one fatty acid chain is missing from the glycerol backbone; lyso-PME, phosphatidylmethylethanolamine where one fatty acid chain is missing from the glycerol backbone; PE, phosphatidylethanolamine; PG, phosphatidylglycerol; PI, phosphatidylinositol; PIM, phosphatidylinositol mannosides; PME, phosphatidylmethylethanolamine. 
The physiological characteristics of Amycolatopsis fastidiosa NRRL B- $16697^{\mathrm{T}}$ were evaluated by the methods of Celmer et al. (1977), Gordon et al. (1974), Shirling \& Gottlieb (1966), de Boer et al. (1990) and Goodfellow et al. (1997, 2001). The differential morphological and physiological properties that distinguish Amycolatopsis fastidiosa from the described species of Actinokineospora are shown in Table 2.

The phylogenetic position of strain NRRL B- $16697^{\mathrm{T}}$, along with its chemotaxonomic profile, clearly place it within the genus Actinokineospora. Production of motile spores, however, is a major trait in the formal description of the genus Actinokineospora (Hasegawa, 1988a); its absence from strain NRRL B-16697 ${ }^{\mathrm{T}}$ requires that the description of the genus be emended to accommodate species that have not been observed to produce them.

\section{Emended description of the genus Actinokineospora Hasegawa 1988b}

Actinokineospora (Ac.ti.no.ki'ne.o.spo'ra. Gr. n. aktis -inos a ray; Gr. v. kineo to set in motion; Gr. fem. n. spora a seed and, in biology, a spore; N.L. fem. n. Actinokineospora actinomycete bearing zoospores).

Form hyphae (approx. $0.5 \mu \mathrm{m}$ in diameter) that differentiate into a vegetative mycelium that penetrates the agar medium and forms colonies on the surface; aerial mycelium arises from the vegetative hyphae. Aerial hyphae generally bear chains of conidia capable of forming flagella in an aqueous environment, although non-motile spores may be produced by some species. Gram-positive. Catalase-positive. Aerobic. The cell wall contains mesodiaminopimelic acid as the diamino acid along with glycine, D-glutamic acid and L-alanine, properties characteristic of a type $\mathrm{A} 1 \gamma$ peptidoglycan. The characteristic whole-cell sugars are arabinose, galactose, mannose and rhamnose, but very little arabinose is found in purified cell walls. The phospholipid pattern consists of significant amounts of phosphatidylethanolamine, including phosphatidylethanolamine containing hydroxylated fatty acids. The principal menaquinone is $\mathrm{MK}-9\left(\mathrm{H}_{4}\right)$. The $\mathrm{G}+\mathrm{C}$ content of the DNA is $69.1-73.0 \mathrm{~mol} \%\left(T_{\mathrm{m}}\right)$. Placed phylogenetically within the suborder Pseudonocardineae

Table 2. Differential physiological properties of the type strains of Actinokineospora species

Strains: 1, Actinokineospora fastidiosa comb. nov. NRRL B-16697 ${ }^{\mathrm{T}}$; 2, Actinokineospora auranticolor NBRC $16518^{\mathrm{T}}$ (data from Otoguro et al., 2001); 3. Actinokineospora diospyrosa NBRC $15665^{\mathrm{T}}$ (Tamura et al., 1995); 4, Actinokineospora enzanensis NBRC 16517 ${ }^{\mathrm{T}}$ (Otoguro et al., 2001); 5, Actinokineospora globicatena NBRC $15664^{\mathrm{T}}$ (Tamura et al., 1995); 6, Actinokineospora inagensis NBRC 15663 ${ }^{\mathrm{T}}$ (Tamura et al., 1995); 7 , Actinokineospora riparia NBRC $14541^{\mathrm{T}}$ (Hasegawa, 1988a); 8, Actinokineospora terrae NBRC $15668^{\mathrm{T}}$ (Tamura et al., 1995). +, Positive reaction or growth; -, negative reaction or no growth; $\mathrm{v}$, variable reaction; w, weak reaction; ND, no data available.

\begin{tabular}{|c|c|c|c|c|c|c|c|c|}
\hline Property & 1 & 2 & 3 & 4 & 5 & 6 & 7 & 8 \\
\hline Colony reverse colour ${ }^{*}$ & $\mathrm{PY} / \mathrm{Y}$ & $\mathrm{O}$ & $\mathrm{Y} / \mathrm{B}$ & G & $\mathrm{Y} / \mathrm{B}$ & $\mathrm{Y} / \mathrm{B}$ & $\mathrm{Y} / \mathrm{B}$ & Ү/в \\
\hline Colour of aerial mycelium ${ }^{\star}$ & $\mathrm{WH} / \mathrm{PP}$ & $\mathrm{WH} / \mathrm{G}$ & $\mathrm{WH} / \mathrm{G}$ & WH & $\mathrm{WH} / \mathrm{G}$ & $\mathrm{WH} / \mathrm{G}$ & WH & $\mathrm{WH} / \mathrm{G}$ \\
\hline Motile spores & - & + & + & + & + & + & + & + \\
\hline Hydrolysis of starch & - & ND & + & ND & + & - & - & + \\
\hline \multicolumn{9}{|l|}{ Production of: } \\
\hline \multicolumn{9}{|c|}{ Growth on sole carbon sources $(1.0 \% \mathrm{w} / \mathrm{v})$ : } \\
\hline L-Arabinose & + & - & - & - & - & - & - & $\mathrm{w}$ \\
\hline D-Fructose & + & - & + & - & + & - & $\mathrm{w}$ & + \\
\hline myo-Inositol & - & - & - & - & - & - & - & - \\
\hline D-Mannitol & - & - & - & - & - & - & - & - \\
\hline Raffinose & + & - & - & - & - & - & - & - \\
\hline \multicolumn{9}{|l|}{ Growth in the presence of: } \\
\hline $2.0 \%(\mathrm{w} / \mathrm{v}) \mathrm{NaCl}$ & + & + & + & + & + & - & + & + \\
\hline $3.0 \%(\mathrm{w} / \mathrm{v}) \mathrm{NaCl}$ & + & $\mathrm{V}$ & + & - & + & - & - & + \\
\hline \multicolumn{9}{|l|}{ Growth at: } \\
\hline $10{ }^{\circ} \mathrm{C}$ & + & + & + & - & + & - & - & + \\
\hline $37{ }^{\circ} \mathrm{C}$ & + & + & V & - & - & - & + & V \\
\hline $45^{\circ} \mathrm{C}$ & + & ND & - & - & - & - & $\mathrm{ND}$ & - \\
\hline
\end{tabular}

${ }^{\star}$ B, Brown; G, grey; O, orange; PP, pale pink; PY, pale yellow; WH, white; Y, yellow. 
based on 16S rRNA gene sequences. The type species is Actinokineospora riparia Hasegawa 1988.

\section{Description of Actinokineospora fastidiosa (Henssen et al. 1987) comb. nov.}

Actinokineospora fastidiosa (fas.ti.di.o'sa. L. fem. adj. fastidiosa fastidious).

Basonym: Amycolatopsis fastidiosa Henssen et al. 1987.

Other synonym: 'Pseudonocardia fastidiosa' Celmer et al. 1977.

The description is based on data from Celmer et al. (1977), Henssen et al. (1987) and the present study. Substrate mycelium is pale yellow to pale salmon, hyphae are irregularly branched, up to $1 \mu \mathrm{m}$ wide and frequently zigzag shaped, occasionally with intercalary swellings. Aerial mycelium is sparse and white to pale pink and spores are rod-shaped, smooth $(1.2-4.5 \mu \mathrm{m})$ and nonmotile. Good growth on complex agar media, but aerial mycelium is only observed on a few media, such as Czapek sucrose agar and inorganic salts-starch agar. Yellowish to brown soluble pigments are produced on several media. Casein, aesculin and tyrosine are hydrolysed, but not allantoin, gelatin, hypoxanthine, starch or xanthine. Nitrate reductase and urease are produced, but hydrogen sulfide is not. Acid is produced from cellobiose and produced weakly from D-fructose but not from adonitol, L-arabinose, dextrin, dulcitol, meso-erythritol, D-galactose, D-glucose, glycerol, glycogen, myo-inositol, lactose, maltose, D-mannitol, D-mannose, melezitose, melibiose, methyl $\alpha$-Dglucoside, D-ribose, raffinose, L-rhamnose, salicin, Dsorbitol, sucrose, trehalose, turanose, D-xylose or xylitol. No utilization of carbohydrates on ISP 9 medium but, when ISP 4 medium without starch is used as the basal medium, L-arabinose, D-fructose, D-glucose, raffinose and D-xylose are utilized, while myo-inositol, D-mannitol and Lrhamnose are not. Sodium citrate, DL-lactic acid and sodium propionate are decarboxylated, but sodium benzoate, sodium mucate, sodium oxalate and sodium Ltartrate are not. Grows in the presence of $5 \% \mathrm{NaCl}$ and at $\mathrm{pH} \mathrm{10;} \mathrm{no} \mathrm{growth} \mathrm{in} \mathrm{lysozyme} \mathrm{broth} \mathrm{or} \mathrm{at} \mathrm{pH} 5$. Temperature range for growth is $10-45^{\circ} \mathrm{C}$, with an optimum of $28{ }^{\circ} \mathrm{C}$. The $\mathrm{G}+\mathrm{C}$ content of the DNA of the type strain is $73 \mathrm{~mol} \%\left(T_{\mathrm{m}}\right)$.

The type strain, NRRL B- $16697^{\mathrm{T}}=\mathrm{DSM} 43855^{\mathrm{T}}=$ ATCC $31181^{\mathrm{T}}=\mathrm{NBRC} 14105^{\mathrm{T}}=\mathrm{JCM} 3276^{\mathrm{T}}=\mathrm{VKM}$ Ac- $1419^{\mathrm{T}}$, was isolated from a soil sample from Egypt.

\section{Acknowledgements}

The able technical assistance of E. N. Hoekstra for physiological characterization and T. Hartman in whole-cell sugar analyses is gratefully acknowledged. Names are necessary to report factually on available data; however, the USDA neither guarantees nor warrants the standard of the product, and the use of the name by USDA implies no approval of the product to the exclusion of others that may also be suitable.

\section{References}

Celmer, W. D., Cullen, W. P., Moppett, C. E., Routien, J. B., Shibakawa, R. \& Tone, J. (1977). Antibiotics produced by species of Pseudonocardia. US Patent 4,031,206.

de Boer, L., Dijkhuizen, L., Grobben, G., Goodfellow, M., Stackebrandt, E., Parlett, J. H., Whitehead, D. \& Witt, D. (1990). Amycolatopsis methanolica sp. nov., a facultatively methylotrophic actinomycete. Int J Syst Bacteriol 40, 194-204.

Everest, G. J. \& Meyers, P. R. (2009). The use of gyrB sequence analysis in the phylogeny of the genus Amycolatopsis. Antonie van Leeuwenhoek 95, 1-11.

Felsenstein, J. (1993). PHYLIP (phylogeny inference package) version 3.5.1. Distributed by the author. Department of Genome Sciences, University of Washington, Seattle, USA.

Goodfellow, M., Brown, A. B., Cai, J., Chun, J. \& Collins, M. D. (1997). Amycolatopsis japonicum sp. nov., an actinomycete producing $(\mathrm{S}, \mathrm{S})$ N,N'-ethylenediaminedisuccinic acid. Syst Appl Microbiol 20, 78-84.

Goodfellow, M., Kim, S. B., Minnikin, D. E., Whitehead, D., Zhou, Z. H. \& Mattinson-Rose, A. D. (2001). Amycolatopsis sacchari sp. nov., a moderately thermophilic actinomycete isolated from vegetable matter. Int J Syst Evol Microbiol 51, 187-193.

Gordon, R. E., Barnett, D. A., Handerhan, J. E. \& Pang, C. H.-N. (1974). Nocardia coeliaca, Nocardia autotrophica, and the nocardin strain. Int J Syst Bacteriol 24, 54-63.

Grund, E. \& Kroppenstedt, R. M. (1989). Transfer of five Nocardiopsis species to the genus Saccharothrix Labeda et al. 1984. Syst Appl Microbiol 12, 267-274.

Hasegawa, T. (1988a). Actinokineospora: a new genus of the Actinomycetales. Actinomycetologica 2, 31-45.

Hasegawa, T. (1988b). Actinokineospora gen. nov. In Validation of the Publication of New Names and New Combinations Previously Effectively Published Outside the IJSB, List no. 27. Int J Syst Bacteriol 38, 449.

Hayakawa, M. \& Nonomura, H. (1987). Humic acid-vitamin agar, a new medium for selective isolation of soil actinomycetes. $J$ Ferment Technol 65, 501-509.

Henssen, A., Kothe, H. W. \& Kroppenstedt, R. M. (1987). Transfer of Pseudonocardia azurea and "Pseudonocardia fastidiosa" to the genus Amycolatopsis, with emended species description. Int J Syst Bacteriol 37, 292-295.

Kimura, M. (1980). A simple method for estimating evolutionary rates of base substitutions through comparative studies of nucleotide sequences. J Mol Evol 16, 111-120.

Labeda, D. P. \& Kroppenstedt, R. M. (2000). Phylogenetic analysis of Saccharothrix and related taxa: proposal for Actinosynnemataceae fam. nov. Int J Syst Evol Microbiol 50, 331-336.

Lechevalier, M. P., De Bièvre, C. \& Lechevalier, H. A. (1977). Chemotaxonomy of aerobic actinomycetes: phospholipid composition. Biochem Syst Ecol 5, 249-260.

Lochhead, A. G. \& Burton, M. O. (1957). Qualitative studies of soil micro-organisms. XIV. Specific vitamin requirements of the predominant bacterial flora. Can J Microbiol 3, 35-42.

Ludwig, W., Strunk, O., Westram, R., Richter, L., Meier, H., Yadhukumar, Buchner, A., Lai, T., Steppi, S. \& other authors (2004). ARB: a software environment for sequence data. Nucleic Acids Res 32, 1363-1371.

Otoguro, M., Hayakawa, M., Yamazaki, T., Tamura, T., Hatano, K. \& limura, Y. (2001). Numerical phenetic and phylogenetic analyses of Actinokineospora isolates, with a description of Actinokineospora auranticolor sp. nov. and Actinokineospora enzanensis sp. nov. Actinomycetologica 15, 30-39. 
Price, N. P. J. (2004). Acylic sugar derivatives for GC/MS analysis of ${ }^{13} \mathrm{C}$-enrichment during carbohydrate metabolism. Anal Chem 76, 6566-6574.

Saitou, N. \& Nei, M. (1987). The neighbor-joining method: a new method for reconstructing phylogenetic trees. Mol Biol Evol 4, 406426.

Shirling, E. B. \& Gottlieb, D. (1966). Methods for characterization of Streptomyces species. Int J Syst Bacteriol 16, 313-340.

Stamatakis, A. P., Ludwig, T., Meier, H. \& Wolf, M. J. (2002). AxML: a fast program for sequential and parallel phylogenetic tree calculations based on the maximum likelihood method. Proc IEEE Comput Soc Bioinform Conf 1, 21-28.

Tamura, T., Hayakawa, M., Nonomura, H., Yokota, A. \& Hatano, K. (1995). Four new species of the genus Actinokineospora: Actinokineospora inagensis sp. nov., Actinokineospora globicatena sp. nov., Actinokineospora terrae sp. nov., and Actinokineospora diospyrosa sp. nov. Int J Syst Bacteriol 45, 371-378.

Tan, G. Y. A., Ward, A. C. \& Goodfellow, M. (2006). Exploration of Amycolatopsis diversity in soil using genus-specific primers and novel selective media. Syst Appl Microbiol 29, 557-569. 